\title{
Impaired comfort in children and adolescents with cancer
}

\author{
Conforto prejudicado em crianças e adolescentes com câncer \\ Conforto perjudicado en niños y adolescentes con cáncer
}

\begin{abstract}
Tânia Alteniza Leandro', Viviane Martins da Silva', Marcos Venícios de Oliveira Lopes',
Nirla Gomes Guedes', Marília Mendes Nunes', Tamires Mesquita de Sousa', Marília Viana Araújo'
'Universidade Federal do Ceará, School of Pharmacology, Dentistry and Nursing. Fortaleza, Ceará, Brazil.
How to cite this article:
$\begin{gathered}\text { Leandro TA, Silva VM, Lopes MVO, Guedes NG, Nunes MM, Sousa TM, et al. Impaired comfort in children and adolescents } \\ \text { with cancer. Rev Bras Enferm [Internet]. 2018;71(3):934-41. DOI: http://dx.doi.org/10.1590/0034-7167-2017-0050 }\end{gathered}$
\end{abstract}
Submission: 03-01-2017 Approval: 05-03-2017

\begin{abstract}
Objective: To determine the strength of the association between the clinical indicators of Impaired Comfort and the evaluation sector in the hospital, age group and sex of patients with cancer. Method: Cross-sectional study, conducted in a children's hospital, with 192 children and adolescents. For the collection, we used an instrument developed for the study. Results: The majority of the sample was male, with mean age of 11 years. The indicators most evidenced among the hospitalized patients were Crying, Report of lack of satisfaction with the situation, Report of feeling cold, and Report of feeling uncomfortable. Crying and Fear were more prevalent in children compared with adolescents, and boys were the ones that verbalized the most the Report of lack of satisfaction with the situation. Conclusion: This study enabled determining the strength of the association of the indicators of Impaired Comfort expressed by children and adolescents with cancer.
\end{abstract}

Descriptors: Nursing Diagnosis; Cancer; Child; Adolescent; Nursing.

\section{RESUMO}

Objetivo: Verificar a força da associação entre os indicadores clínicos de Conforto prejudicado e o setor de avaliação no hospital, a faixa etária e o sexo de pacientes com câncer. Método: Estudo transversal, realizado em um hospital pediátrico, com 192 crianças e adolescentes. Para a coleta, utilizou-se um instrumento desenvolvido para o estudo. Resultados: A maior parte da amostra era do sexo masculino, com idade mediana de 11 anos. Choro, Relato de falta de satisfação com a situação, Relato de sentir frio e Relato de sentir-se desconfortável foram os indicadores mais evidenciados entre os pacientes internados. Choro e Medo estiveram mais prevalentes nas crianças em comparação aos adolescentes, sendo que os meninos foram os que mais verbalizaram o Relato de falta de sentir-se à vontade com a situação. Conclusão: O estudo possibilitou verificar a força de associação dos indicadores de Conforto prejudicado manifestados por crianças e adolescentes com câncer.

Descritores: Diagnóstico de Enfermagem; Câncer; Criança; Adolescente; Enfermagem.

\section{RESUMEN}

Objetivo: Verificar la fuerza de la asociación entre los indicadores clínicos de Conforto perjudicado y el sector de evaluación en el hospital, la franja de edad y el sexo de pacientes con cáncer. Método: Estudio transversal, realizado en un hospital pediátrico, con 192 niños y adolescentes. Para la recogida, se utilizó un instrumento desarrollado para el estudio. Resultados: La parte más grande de la muestra era del sexo masculino, con edad promedio 11 años. Llanto, Relato de falta de satisfacción con la situación, Relato de sentir frío y Relato de sentirse no confortable fueron los indicadores más evidenciados entre los pacientes internados. Llanto y Miedo estuvieron más prevalentes en los niños en comparación a los adolescentes, siendo que los niños fueron los que más verbalizaron el Relato de falta de sentirse a gusto con la situación. Conclusión: El estudio posibilitó verificar la fuerza de la asociación de los indicadores de Conforto perjudicado manifestados por niños y adolescentes con cáncer.

Descriptores: Diagnóstico de Enfermería; Cáncer; Niño; Adolescente; Enfermería. 


\section{INTRODUCTION}

Cancer has low occurrence ${ }^{(1)}$ in children and adolescents compared with adults or the elderly. In Brazil and in developed countries, cancer is the leading cause of death by disease among children and adolescents aged 1 to 19 years $^{(2)}$. For 2017, 12,600 cases were estimated in Brazil. In 2013, there were 2,835 deaths in the age group between 0 and 19 years $^{(2)}$. Data from the Ministry of Health show a decrease in the number of deaths of children and adolescents by infectious and parasitic diseases, circulatory and respiratory system diseases, and disorders originated in the neonatal period. However, deaths by neoplasms and external causes gain importance ${ }^{(3)}$.

The signs and symptoms of childhood cancer are: pallor, fatigue, weakness, pain, fever, abnormal bruising, lymphadenopathies and recurrent infections ${ }^{(4)}$, which resemble the clinical manifestations of other common diseases of childhood. Therefore, effective and accessible approaches to early diagnosis are important, since approximately $80 \%$ of children and adolescents affected by cancer can be cured if diagnosed early and treated in specialized centers ${ }^{(5)}$. Thus, after confirmation of the diagnosis of malignant neoplasm, it is necessary to initiate proper treatment in a pediatric oncology unit with structure to support this treatment.

The treatment of patients with cancer is quite complex and diverse, so each therapy will depend on the etiology of the disease and the patient's response. It is believed that the hospital environment, the period of hospitalization, the treatment, the waiting time for outpatient appointments, the physiopathology of the disease, and the procedures performed in children and adolescents with cancer can cause the appearance of clinical indicators that suggest the occurrence of the Impaired Comfort nursing diagnosis.

The Impaired Comfort nursing diagnosis was included in the Nursing Diagnosis List of NANDA International in 2008. It is found in domain 12 (comfort) and in the class of physical comfort, environmental comfort, and social comfort. It is defined as: "Perceived lack of ease, relief and transcendence in physical, psychospiritual, environmental, and social dimensions ${ }^{(6)} . "$

It is worth mentioning that the nursing diagnosis is constituted by the grouping of clinical indicators, that is, of signs and symptoms that aid in determining the absence or presence of a specific diagnosis ${ }^{(6)}$. For diagnostic inference, nurses should develop skills that aid them in decision-making considering clinical manifestations expressed as signs and symptoms ${ }^{(7)}$. The nursing diagnosis represents the interpretations about the patient data, being defined as clinical judgment about the responses of an individual, family, or community to the health problems/actual or potential life processes ${ }^{(6)}$.

\section{OBJECTIVE}

To determine the strength of the association between the clinical indicators of Impaired Comfort and the evaluation sector in the hospital, age group and sex of patients with cancer.

\section{METHOD}

\section{Ethical aspects}

The study met the recommendations for research developed with human beings and was submitted to and approved by the Research Ethics Committee of the participating institution. Those responsible for the children and adolescents who composed the sample ensured their participation in the study by signing the free and informed consent form. All adolescent participants signed the Term of Assent.

\section{Study design, location, and period}

Cross-sectional study, conducted in a reference center specializing in children and adolescent cancer treatment, in the Brazilian Northeast. Data were collected in three different sectors of the center: day hospital, inpatient unit, and sequential chemotherapy unit. The collection period occurred between the months of September 2014 and February 2015.

\section{Sample, inclusion criteria, and exclusion criteria}

Sample calculation was based on the number of clinical indicators of the Impaired Comfort diagnosis. The study adopted an estimate of five children for each indicator. Impaired Comfort has 17 clinical indicators, therefore $5 \times 17$, totaling a sample of at least 85 participants in each group (day hospital and inpatient unit). Thus, we evaluated two groups of the population: in the first, it was possible to evaluate 106 children and adolescents of the day hospital and, in the second, 86 children and adolescents in the inpatient unit. Therefore, this study had participation of 192 children and adolescents with cancer under chemotherapy treatment. The subjects were obtained by a process of successive sampling.

The research adopted the following inclusion criteria: age from 6 to 18 years; medical diagnosis of cancer; being under chemotherapy treatment and clinically stable. The exclusion criteria were: children and adolescents with comorbidities that could influence the identification of the diagnosis of Impaired Comfort and/or use of antipsychotics, anxiolytics, and antidepressants. In this study, a child was excluded for use of antipsychotics, anxiolytics, and antidepressants.

The age group was established with the aim of evaluating the Impaired Comfort in the entire sample (children and adolescents). Since the aforementioned diagnosis has subjective indicators, the cutoff age to include the patients in the child group was established as $\geq 6$ years (school age), that is, those considered able to answer questions. For the adolescent group, we included the individuals in the age group 12-18 years, as defined by the Ministry of Health ${ }^{(8)}$.

\section{Study protocol}

Data were collected by three nurses, through an instrument adapted from a previous study ${ }^{(9)}$. Prior to initiating the data collection step, the collection team was invited to a training, in order to standardize the way of obtaining the information and avoid bias during the evaluations. 
The child or adolescent and the respective parent/guardian were interviewed so as to obtain identification and sociodemographic data, such as: name, sex, age, date of birth, origin, birthplace, household income, number of family members, and school data. Also during the interview, we obtained information about clinical data of the child/adolescent. Having these data, we collected objective and subjective information regarding the signs and symptoms of the nursing diagnosis Impaired Comfort, presented by the children and adolescents, namely: Anxiety, Crying, Inability to relax, Restlessness, Irritability, Grief, Fear, Disturbed sleep pattern, Report of lack of satisfaction with the situation, Report of lack of feeling comfortable with the situation, Report of hunger, Report of pruritus, Report of feeling hot, Report of feeling cold, Report of feeling uncomfortable, Report of symptoms of distress, and Sighs.

After collecting all the abovementioned information, we referred to the medical chart of each child and adolescent to obtain information related to: chart number, initials of the name, date of birth, date of hospitalization, medical diagnosis, start of chemotherapy treatment, stage of chemotherapy treatment, and protocol used for the chemotherapy sessions.

It should be noted that the data were collected from a primary source. When the subject of the study showed no conditions of replying to questions with trustworthiness, the interview was conducted with the parent/guardian.

\section{Analysis of results and statistics}

Statistical analysis was developed with support of statistical program IBM ${ }^{\circledast}$ SPSS $^{\circledast}$ version 21.0 for Windows ${ }^{\circledast}$ and software $\mathrm{R}$ version 2.12.1. Descriptive analysis of data included the calculation of absolute frequencies, percentages, measures of central tendency and dispersion. For the proportions of categorical variables, we calculated confidence intervals of $95 \%$. We used Pearson's Chi-Squared Test to analyze the association between the nominal variables and the presence of the nursing diagnosis in question. To determine the adherence to normal distribution, we applied the Kolmogorov-Smirnov test.

\section{RESULTS}

Of the 192 participants of the research, 55.2\% were evaluated at the day hospital, $53.6 \%$ were children, and $53.1 \%$ were male. More than $60 \%$ of the sample were from cities in the countryside of the state. A high percentage of participants $-63.5 \%$ of the children and adolescents - did not attend school because of the disease. It should be noted that $89.1 \%$ of the individuals had no comorbidities. The majority of the sample $(70.8 \%)$ had no family history for cancer. As to being submitted to surgery to correct the disease, $75 \%$ of the children and adolescents had no need for this type of intervention during treatment.

The patients evaluated had median age of 11 years. The median household income of the parents/guardians was of $\mathrm{R} \$ 724.00$, with median of four persons in the household. The time of treatment of the children and adolescents in the hospital unit presented median of five months. The number of chemotherapy treatments had a median of one treatment.
As to the days of hospitalization, the median was of four days, and the number of hospitalizations in the last 12 months had a median of two hospitalizations.

Leukemias $(45.3 \%)$, Lymphomas $(16.1 \%)$, malignant bone tumors $(14.6 \%)$, and soft tissue Sarcomas $(10.9 \%)$ were the types of cancer most identified in the patients. When the medical diagnoses were specified, the following subtypes were the most prevalent: Acute Lymphoblastic Leukemia (33.9\%) and Osteosarcoma $(12 \%)$. In relation to the stage of chemotherapy treatment, $20.8 \%$ of the sample were in the stage of maintenance.

We conducted statistical association tests to compare the children and adolescents evaluated in the day hospital with those of the inpatient unit in relation to $\operatorname{sex}(p=0.928)$, origin $(p=0.602)$, birthplace $(p=0.631)$, attends school $(p=0.089)$, comorbidities $(p=0.095)$, family history for cancer $(p=0.506)$, submitted to surgical procedure $(p=0.867)$, and medical diagnosis $(p=0.078)$. It is observed that the tests applied indicate that these variables are not statistically significant between the groups evaluated in the inpatient unit and in the day hospital ( $p>0.05)$.

The clinical indicators of the nursing diagnosis Crying $(p=0.013)$, Report of lack of satisfaction with the situation $(p=0.000)$, Report of feeling cold $(p=0.000)$, and Report of feeling uncomfortable $(p=0.000)$ showed significant statistical association with the evaluation sector. These were more evidenced in children and adolescents who were in the inpatient unit (Table 1).

Analyses were performed comparing the children group $x$ adolescents group with the variables sex $(p=0.835)$, origin $(p=0.036)$, birthplace $(p=0.267)$, attends school $(p=0.101)$, comorbidities $(p=0.083)$, family history for cancer $(p=0.198)$, submitted to surgical procedure $(p=0.802)$, and medical diagnosis $(p=0.297)$. The origin of the participants showed statistical difference between the groups children $x$ adolescents $(p<0.005)$. Therefore, the proportion of children coming from countryside cities to undergo cancer treatment is higher than that of adolescents.

When performing statistical association between the clinical indicators of the diagnosis with the children group versus adolescents group, Crying $(p=0.000)$ and Fear $(p=0.000)$ showed significant statistical association with the age group variable, meaning that the presence of crying and fear was more prevalent and significant for the children group (Table 2).

We carried out association analyses between the variables origin $(p=0.123)$, birthplace $(p=0.001)$, attends school $(p=0.955)$, comorbidities $(p=0.318)$, family history for cancer $(p=0.474)$, submitted to surgical procedure $(p=0.867)$, and medical diagnosis $(p=0.467)$ comparing with the male and female subgroups. Accordingly, the test applied showed statistically significant difference for the birthplace variable when comparing the male and female subsamples $(p<0.005)$. Therefore, the data show that, of the patients coming from the countryside, the majority was male.

When evaluating both sexes, the indicator Report of lack of feeling comfortable with the situation presented statistical association with the male patients ( $p=0.033$ ). Thus, boys verbalized more the Report of lack of feeling comfortable with the situation (Table 3). 
Table 1 - Association between the clinical indicators of Impaired Comfort and the evaluation sector in the treatment unit

\begin{tabular}{|c|c|c|c|}
\hline Clinical indicators & Day hospital & $\begin{array}{l}\text { Inpatient } \\
\text { unit }\end{array}$ & $\underset{\text { value* }}{p}$ \\
\hline \multicolumn{4}{|l|}{ Anxiety } \\
\hline Absent & 88 & 69 & \multirow{2}{*}{0.915} \\
\hline Present & 16 & 12 & \\
\hline \multicolumn{4}{|l|}{ Crying } \\
\hline Absent & 61 & 34 & \multirow{2}{*}{0.013} \\
\hline Present & 45 & 52 & \\
\hline \multicolumn{4}{|l|}{ Inability to relax } \\
\hline Absent & 88 & 67 & \multirow{2}{*}{0.372} \\
\hline Present & 18 & 19 & \\
\hline \multicolumn{4}{|l|}{ Restlessness } \\
\hline Absent & 74 & 52 & \multirow{2}{*}{0.175} \\
\hline Present & 32 & 34 & \\
\hline \multicolumn{4}{|l|}{ Irritability } \\
\hline Absent & 49 & 37 & \multirow{2}{*}{0.657} \\
\hline Present & 57 & 49 & \\
\hline \multicolumn{4}{|l|}{ Grief } \\
\hline Absent & 93 & 70 & \multirow{2}{*}{0.222} \\
\hline Present & 13 & 16 & \\
\hline \multicolumn{4}{|l|}{ Fear } \\
\hline Absent & 55 & 39 & \multirow{2}{*}{0.367} \\
\hline Present & 51 & 47 & \\
\hline \multicolumn{4}{|c|}{ Disturbed sleep pattern } \\
\hline Absent & 83 & 63 & \multirow{2}{*}{0.415} \\
\hline Present & 23 & 23 & \\
\hline \multicolumn{4}{|c|}{$\begin{array}{l}\text { Report of lack of satisfaction with } \\
\text { the situation }\end{array}$} \\
\hline Absent & 61 & 23 & \multirow{2}{*}{0.000} \\
\hline Present & 45 & 63 & \\
\hline \multicolumn{4}{|c|}{$\begin{array}{l}\text { Report of lack of feeling } \\
\text { comfortable with the situation }\end{array}$} \\
\hline Absent & 54 & 37 & \multirow{2}{*}{0.274} \\
\hline Present & 52 & 49 & \\
\hline \multicolumn{4}{|l|}{ Report of pruritus } \\
\hline Absent & 89 & 65 & \multirow{2}{*}{0.147} \\
\hline Present & 17 & 21 & \\
\hline \multicolumn{4}{|l|}{ Report of hunger } \\
\hline Absent & 86 & 60 & \\
\hline Present & 20 & 26 & $0.06 /$ \\
\hline Report of feeling ho & & & \\
\hline Absent & 79 & 70 & 0.256 \\
\hline Present & 27 & 16 & 0.256 \\
\hline Report of feeling cc & & & \\
\hline Absent & 80 & 30 & 0000 \\
\hline Present & 26 & 56 & 0.000 \\
\hline Report of feeling un & & & \\
\hline Absent & 27 & 05 & \\
\hline Present & 79 & 81 & 0.000 \\
\hline Report of symptoms & & & \\
\hline Absent & 94 & 79 & 0463 \\
\hline Present & 12 & 07 & 0.463 \\
\hline
\end{tabular}

Note: *Pearson's Chi-Squared Test
Table 2 - Association between the clinical indicators of the Impaired Comfort diagnosis and the age group variable

\begin{tabular}{|c|c|c|c|}
\hline Clinical indicators & $\underset{n}{\text { Child }}$ & $\begin{array}{l}\text { Adolescent } \\
n\end{array}$ & $\underset{\text { value* }}{p}$ \\
\hline \multicolumn{4}{|l|}{ Anxiety } \\
\hline Absent & 83 & 74 & \multirow{2}{*}{0.780} \\
\hline Present & 14 & 14 & \\
\hline \multicolumn{4}{|l|}{ Crying } \\
\hline Absent & 35 & 60 & \multirow{2}{*}{0.000} \\
\hline Present & 68 & 29 & \\
\hline \multicolumn{4}{|l|}{ Inability to relax } \\
\hline Absent & 88 & 67 & \multirow{2}{*}{0.075} \\
\hline Present & 15 & 22 & \\
\hline \multicolumn{4}{|l|}{ Restlessness } \\
\hline Absent & 65 & 61 & \multirow{2}{*}{0.429} \\
\hline Present & 38 & 28 & \\
\hline \multicolumn{4}{|l|}{ Irritability } \\
\hline Absent & 45 & 41 & \multirow{2}{*}{0.471} \\
\hline Present & 58 & 48 & \\
\hline \multicolumn{4}{|l|}{ Grief } \\
\hline Absent & 83 & 80 & \multirow{2}{*}{0.073} \\
\hline Present & 20 & 09 & \\
\hline \multicolumn{4}{|l|}{ Fear } \\
\hline Absent & 38 & 56 & \multirow{2}{*}{0.000} \\
\hline Present & 65 & 33 & \\
\hline \multicolumn{4}{|c|}{ Disturbed sleep pattern } \\
\hline Absent & 77 & 69 & \multirow{2}{*}{0.654} \\
\hline Present & 26 & 20 & \\
\hline \multicolumn{4}{|c|}{$\begin{array}{l}\text { Report of lack of satisfaction with } \\
\text { the situation }\end{array}$} \\
\hline Absent & 39 & 45 & \multirow{2}{*}{0.077} \\
\hline Present & 64 & 44 & \\
\hline \multicolumn{4}{|c|}{$\begin{array}{l}\text { Report of lack of feeling comfortable } \\
\text { with the situation }\end{array}$} \\
\hline Absent & 43 & 48 & \multirow{2}{*}{0.092} \\
\hline Present & 60 & 41 & \\
\hline \multicolumn{4}{|l|}{ Report of pruritus } \\
\hline Absent & 82 & 72 & \multirow{2}{*}{0.823} \\
\hline Present & 21 & 17 & \\
\hline \multicolumn{4}{|l|}{ Report of hunger } \\
\hline Absent & 81 & 65 & \\
\hline Present & 22 & 24 & 0.364 \\
\hline Report of feeling ho & & & \\
\hline Absent & 81 & 68 & 0711 \\
\hline Present & 22 & 21 & 0.711 \\
\hline Report of feeling co & & & \\
\hline Absent & 57 & 53 & 0.556 \\
\hline Present & 46 & 36 & 0.350 \\
\hline Report of feeling ur & & & \\
\hline Absent & 19 & 13 & 0.477 \\
\hline Present & 84 & 76 & $0.4 / 7$ \\
\hline Report of symptom & & & \\
\hline Absent & 90 & 83 & 0174 \\
\hline Present & 14 & 06 & 0.174 \\
\hline
\end{tabular}

Note: *Pearson's Chi-Squared Test 
Table 3 - Association between the clinical indicators of the Impaired Comfort diagnosis and the sex variable

\begin{tabular}{|c|c|c|c|}
\hline Clinical indicators & $\underset{n}{\text { Male }}$ & $\underset{n}{\text { Female }}$ & $\underset{\text { value* }}{p}$ \\
\hline \multicolumn{4}{|l|}{ Anxiety } \\
\hline Absent & 85 & 72 & \multirow{2}{*}{0.686} \\
\hline Present & 14 & 14 & \\
\hline \multicolumn{4}{|l|}{ Crying } \\
\hline Absent & 57 & 38 & \multirow{2}{*}{0.059} \\
\hline Present & 45 & 52 & \\
\hline \multicolumn{4}{|l|}{ Inability to relax } \\
\hline Absent & 83 & 72 & \multirow{2}{*}{0.810} \\
\hline Present & 19 & 18 & \\
\hline \multicolumn{4}{|l|}{ Restlessness } \\
\hline Absent & 66 & 60 & \multirow{2}{*}{0.775} \\
\hline Present & 36 & 30 & \\
\hline \multicolumn{4}{|l|}{ Irritability } \\
\hline Absent & 46 & 40 & \multirow{2}{*}{0.928} \\
\hline Present & 56 & 50 & \\
\hline \multicolumn{4}{|l|}{ Grief } \\
\hline Absent & 87 & 76 & \multirow{2}{*}{0.870} \\
\hline Present & 15 & 14 & \\
\hline \multicolumn{4}{|l|}{ Fear } \\
\hline Absent & 51 & 43 & \multirow{2}{*}{0.759} \\
\hline Present & 51 & 47 & \\
\hline \multicolumn{4}{|c|}{ Disturbed sleep pattern } \\
\hline Absent & 73 & 73 & \multirow{2}{*}{0.122} \\
\hline Present & 29 & 17 & \\
\hline \multicolumn{4}{|c|}{$\begin{array}{l}\text { Report of lack of satisfaction with } \\
\text { the situation }\end{array}$} \\
\hline Absent & 44 & 40 & \multirow{2}{*}{0.855} \\
\hline Present & 58 & 50 & \\
\hline \multicolumn{4}{|c|}{$\begin{array}{l}\text { Report of lack of feeling } \\
\text { comfortable with the situation }\end{array}$} \\
\hline Absent & 41 & 50 & \multirow{2}{*}{0.033} \\
\hline Present & 61 & 40 & \\
\hline \multicolumn{4}{|l|}{ Report of pruritus } \\
\hline Absent & 83 & 71 & \multirow{2}{*}{0.666} \\
\hline Present & 19 & 19 & \\
\hline \multicolumn{4}{|l|}{ Report of hunger } \\
\hline Absent & 76 & 70 & 0597 \\
\hline Present & 26 & 20 & 0.591 \\
\hline Report of feeling ho & & & \\
\hline Absent & 84 & 65 & 0.093 \\
\hline Present & 18 & 25 & 0.093 \\
\hline Report of feeling co & & & \\
\hline Absent & 59 & 51 & \\
\hline Present & 43 & 39 & 0.869 \\
\hline Report of feeling unc & & & \\
\hline Absent & 16 & 16 & \\
\hline Present & 86 & 74 & 0.698 \\
\hline Report of symptoms & & & \\
\hline Absent & 91 & 81 & \\
\hline Present & 10 & 09 & 0.964 \\
\hline
\end{tabular}

Note: *Pearson's Chi-Squared Test

\section{DISCUSSION}

Rates for child/adolescent cancers are usually higher in boys, similar to that which was observed in our study, which accounted for $53.1 \%$ male participants. Previous research corroborates the data observed. In an epidemiological study conducted with adolescents with cancer, $56.8 \%$ of the participants were boys ${ }^{(10)}$. In relation to the population of children, boys are also more affected by the disease - a study reported a percentage of $63.8 \%$ of the cases ${ }^{(11)}$.

The research had participation of children and adolescents with median age of 11 years and $53.6 \%$ of them belonged to the children subgroup, that is, patients aged $\geq 6$ years. Most evaluations were conducted at the day hospital (55.2\%). A research conducted in the pediatric oncology sector showed similar data to those of this study. In such research, the participants had median age of 12 years $^{(12)}$.

The subjects had median household income of $R \$ 724.00$ and mean of four persons per household. This value refers to the minimum wage in force at the time of the study's data collection (2014-2015). Corroborating the data from this study, other authors found households of individuals with cancer whose monthly income was of one minimum wage and observed difficulties such as: abandonment of employment and availability of time for treatment ${ }^{(13-15)}$. Additionally, another research found households composed of, on average, 3.8 persons per house ${ }^{(16)}$. Many parents or guardians reported that the long period of treatment of the disease, constant hospitalizations, and distance from the residence to the treatment center were factors that interfered with the maintenance of employment and, as a result, they needed to abandon it so as to accompany their children during treatment. Thus, sickness benefit was often the household's only source of income.

The participants of our research came mostly from the countryside of the state. It is worth mentioning that the institution where the research was conducted is a benchmark in the treatment of child/adolescent cancer in northeastern Brazil. Thus, patients from countryside cities or even from other states come to have treatment in the institution, which may justify the high prevalence of persons from the countryside under treatment in the unit. Studies in other states with the same patients result in similar situation: children and adolescents from countryside cities $^{(15)}$.

The abandonment of school activities during treatment is a very common situation. Many children and adolescents reported not attending school because of cancer, of the effects of treatment, hospitalizations, frequent appointments, among others. Research confirms such findings, since, in most cases, during cancer treatment they abandon school due to frequent hospitalizations and toxicities of chemotherapeutic agents ${ }^{(14-15,17)}$. We perceived - in the participants' discourse sadness for the need to abandon school activities and socialization with schoolmates.

Generally, the treatment of cancer is related to chemotherapy, surgery, and/or radiation therapy. In childhood cancer, chemotherapy is an important therapeutic component, since most diseases are sensitive to chemotherapeutic agents, which justifies 
the low occurrence of surgical procedures for treatment of the disease in the children population. In this study, $75 \%$ of the participants had not been submitted to this procedure.

The time of treatment of the children and adolescents in the hospital unit ranged from zero to 57 months, with median of five months. In relation to the number of chemotherapy treatments, the participants showed a median of at least one treatment. The median for the days of hospitalization and number of hospitalizations in the last 12 months variables was of at least four days and two hospitalizations, respectively. A study conducted with children under palliative care showed a mean of 2.5 hospitalizations ${ }^{(18)}$. Another research, conducted with children with cancer in the outpatient clinic, showed that, for $33.3 \%$ of the participants, the treatment period did not exceed six months and $76.6 \%$ had been hospitalized two or more times ${ }^{(19)}$. The treatment of cancer is long and delicate, requiring more than one hospitalization and frequent appointments.

Acute Lymphoblastic Leukemia is the most common type of childhood Leukemia ${ }^{(3)}$. This affirmation corroborates the results of our study, in which most of the population had leukemia and the most prevalent was Acute Lymphoblastic Leukemia $(45.3 \%$ and $33.9 \%$, respectively). Among the lymphomas, the most common in childhood is the non-Hodgkin's Lympho$\mathrm{ma}^{(20)}$. In our research, this was the type of lymphoma most commonly observed in the children and adolescents (7.8\%). The most common malignant bone tumors in childhood, the Ewing tumor and Osteosarcoma, represent $5 \%$ of the cancers in children ${ }^{(21)}$. In this study, they were the third most prevalent type of tumor in the population, with $14.6 \%$ of the cases. In relation to the subtype, osteosarcoma predominated.

In relation to the stage of chemotherapy treatment, $20.8 \%$ of the population were in the maintenance stage. The treatment is divided into stages, and the maintenance stage is the most extensive ${ }^{(22)}$. Therefore, the high incidence of children and adolescents in this stage in this study is due to the fact that it corresponds to the longest period of treatment.

When analyzing the association of the indicators, Crying, Report of lack of satisfaction with the situation, Report of feeling cold, and Report of feeling uncomfortable were more evidenced in hospitalized children/adolescents. The Crying and Fear indicators were more prevalent when evaluated in the children subsample.

Crying is a common reaction in the children and in the hospitalized population, especially to an aggressive and painful treatment such as that of cancer. Often, learning about the hospitalization causes crying in children and adolescents, because it is an event associated with negative health factors. In the specific group of children, crying is often related with Fear. In a study conducted with a group of children during the hospitalization period, the emotional reaction Fear was the most identified $(37.8 \%)$. The hospital environment is related to some situations that cause natural reaction of Fear before the possibility of invasive procedures ${ }^{(23)}$.

When evaluating the differences between the indicators presented, we observed that Report of lack of feeling comfortable with the situation showed to be more prevalent among boys, while for the girls the Crying indicator was highlighted.
It is known that most of the child/adolescent cancers are more frequent in the male population ${ }^{(3)}$ and, therefore, this group is more susceptible to the harmful and traumatic effects of chemotherapy treatment, as well as to the effects of the disease itself, which may justify the Report of lack of feeling comfortable with the situation indicator being the most prevalent in the male population. In addition, this indicator showed significant statistical association for the male participants.

On the other hand, among girls the Crying indicator was more evidenced due to the fact that, often, it is not externalized by boys because of the still sexist raising, incorporated since childhood, of absence of crying for the male population. As mentioned, a child's main reaction to Fear is Crying. Therefore, the treatment of disease and the hospital environment itself cause a feeling of Fear in the child and, consequently, the reaction of Crying. A prior study, evaluating children with cancer under chemotherapy treatment, observed that girls are more likely to present psychological stress, because, generally, the women are more sensitive to the events of their lives ${ }^{(24)}$. This event may, also, justify the presence of Crying in this subsample during the experience of cancer.

Report of feeling cold and Report of feeling uncomfortable were also significant indicators for the group of hospitalized participants. Martins ${ }^{(25)}$ observed similar findings, showing the relationship between hospital procedures and the presence of thermal discomfort. In addition, hospitalization may generate anxiety in patients and, consequently, physiological reactions responsible for alterations in blood pressure and temperature $^{(23)}$. Furthermore, the high number of reports of discomfort in hospitalized patients may be justified by the exposure to the various procedures of hospital routine ${ }^{(26-27)}$.

\section{Study limitations}

The scarcity of studies conducted with the Impaired Comfort nursing diagnosis limited the comparison of the results for the clinical indicators presented by this specific population. Noteworthy, we found no published research on the above diagnosis in children and adolescents with cancer. Furthermore, the method used did not enable describing temporal relationships between the variables, that is, it did not enable determining the influence of the indicators on the progression of the diagnosis; therefore, there may be other important aspects to the comfort of this population that, perhaps, have not been determined.

\section{Contributions to the fields of nursing, health, or public policies}

Nursing professionals are directly related to the promotion of comfort to their patients. Thus, determining the clinical indicators of Impaired Comfort associated with children and adolescents under chemotherapy treatment becomes relevant to the nursing practice in Pediatric Oncology, as this knowledge will aid in interventions directed to the etiological factors of the diagnosis during cancer treatment and will enable promoting quality care geared towards this population. It is suggested that further studies are conducted to deepen the knowledge of the presence of this diagnosis in the children population. 


\section{CONCLUSION}

Our results enabled determining the strength of the association of sociodemographic and clinical data with the clinical indicators of Impaired Comfort in children and adolescents with cancer. Thus, the indicator Report of lack of feeling comfortable with the situation presented statistical association with the male patients. Crying and Fear presented significant statistical association with the children group. Finally, four indicators had significant statistical relation with the evaluation sector (inpatient unit): Crying, Report of lack of satisfaction with the situation, Report of feeling cold, and Report of feeling uncomfortable.

\section{REFERENCES}

1. Brasil. Ministério da Saúde. Instituto Nacional de Câncer José Alencar Gomes da Silva. ABC do câncer: abordagens básicas para o controle do câncer. 2 ed. Rio de Janeiro: INCA; 2012.

2. Brasil. Ministério da Saúde. Instituto Nacional de Câncer. Tipos de câncer infantil [Internet]. Rio de Janeiro, INCA; 2016[cited 2017 Apr 6]. Available from: http://www2.inca.gov.br/wps/wcm/connect/tiposdecancer/site/home/infantil

3. Brasil. Ministério da Saúde. Instituto Nacional de Câncer. Diagnóstico precoce do câncer na criança e no adolescente. Instituto Nacional de Câncer, Instituto Ronald Mcdonald. 2 ed. rev. ampl. Rio de Janeiro: INCA; 2013.

4. Figueiredo NM, Leite JL, Machado WCA, Moreira MC, Tonini T. Enfermagem oncológica: conceitos e práticas. São Caetano do Sul, SP: Yendis Editora; 2013.

5. Ceará. Governo do Estado de Ceará. Diagnóstico precoce aumenta chances de cura do câncer infantil[Internet]. 2014 [cited 2017 Apr 6]. Available from: http://www.hias.ce.gov.br/index.php/noticias/57130-cancerinfantil

6. Herdman TH. Diagnósticos de enfermagem da NANDA: definições e classificação 2012-2014. Porto Alegre: Artmed, 2013.

7. Silva ERR. Diagnósticos de enfermagem com base em sinais e sintomas. Porto Alegre: Artmed; 2011.

8. Brasil. República Federativa do Brasil. Estatuto da criança e do adolescente: Lei nº 8.069, de 13 de julho de 1990, e legislação correlata. 13 ed. Brasília: Câmara dos Deputados; 2015.

9. Leandro TA. Acurácia das características definidoras do diagnóstico de enfermagem: conforto prejudicado em crianças com câncer. [Monografia]. Departamento de Enfermagem, Universidade Federal do Ceará. Fortaleza, 2012. $57 \mathrm{f}$

10. Presti PF, Macedo CRD, Caran R, Petrilli AS. Epidemiological study of cancer in adolescents at a referral center. Rev Paul Pediatr [Internet]. 2012 [cited 2015 Jan 8];30(2):210-16. Available from: http://www.scielo.br/pdf/rpp/v30n2/en_09.pdf

11. Elman I, Soares NS, Silva MEMP. Análise da sensibilidade do gosto Umami em crianças com câncer. Rev Bras Cancerol [Internet]. 2010 [cited 2014 Dec 17];56(2):237-42. Available from: http://www.inca.gov.br/rbc/n_56/v02/pdf/09_artigo_analise_ sensibilidade_gosto_umami.pdf

12. Benites EC, Cabrini DP, Silva AC, Silva JC, Catalan DT, Berezin EN, et al. Acute respiratory viral infections in pediatric cancer patients undergoing chemotherapy. J Pediatr [Internet]. 2014[cited 2015 Jan 15];90(4):370-6. Available from: http://www.scielo. br/pdf/jped/v90n4/0021-7557-jped-90-04-00370.pdf

13. Sanchez KOL, Ferreira NMLA. Social support for the families of patients with cancer living in poverty. Texto Contexto Enferm [Internet]. 2012 [cited 2015 Jan 21];21(4):792-9. Available from: http://www.scielo.br/pdf/tce/v21n4/en_09.pdf

14. Sime MM, Shishido NS, Santos WA. Caracterização do perfil da clientela do setor de terapia ocupacional na oncologia pediátrica. Rev Bras Cancerol [Internet]. 2011 [cited 2014 Dec 15];57(2):167-75. Available from: http://www1.inca.gov.br/rbc/n_57/v02/ pdf/04_artigo_caracterizacao_perfil_clientela_setor_terapia_ocupacional_oncologia_pediatrica.pdf

15. Viaro VD, Silva KV. Qualidade de vida dos adolescentes curados de câncer: uma abordagem qualitativa e interdisciplinar. Adolesc Saude [Internet]. 2012 [cited 2015 Feb 1];9(1):39-45. Available from: http://www.adolescenciaesaude.com/detalhe_artigo.asp?id=305

16. Oliveira LN, Breigeiro NB, Márcia K, Hallmanna S, Witkowski MC. Vulnerabilities of children admitted to a pediatric inpatient care unit. Rev Paul Pediatr [Internet]. 2014 [cited 2015 Jan 6];32(4):367-73. Available from: http://www.scielo.br/pdf/rpp/v32n4/01030582-rpp-32-04-00367.pdf

17. Gomes IP, Lima KA, Rodrigues LV, Lima RAG, Collet N. From diagnosis to survival of pediatric cancer: children's perspective. Texto Contexto Enferm [Internet]. 2013 [cited 2015 Jan 13];22(3):671-9. Available from: http://www.scielo.br/pdf/tce/v22n3/en_ v22n3a13.pdf

18. Garcia NR, Pacciulio AM, Panúncio-Pinto MP, Pfeifer LI. Intervenção terapêutica ocupacional junto a adolescentes com câncer em contexto hospitalar. Rev Bras Cancerol [Internet]. 2011 [cited 2015 Jan 8];57(4):519-24. Available from: http://www.inca.gov.br/ rbc/n_57/v04/pdf/08_artigo_intervencao_terapeutica_ocupacional_junto_adolescentes_com_cancer_em_contexto_hospitalar.pdf

19. Artilheiro APS, Almeida FA, Chacon JMF. Use of therapeutic play in preparing preschool children for outpatient chemotherapy. Acta Paul Enferm [Internet]. 2011[cited 2015 Jan 20];24(5):611-6. Available from: http://www.scielo.br/pdf/ape/v24n5/en_03v24n5.pdf

20. Brasil. Ministério da Saúde. Instituto Nacional de Câncer. Tipos de câncer infantil [Internet]. Rio de Janeiro: INCA; 2017[cited 2017 Apr 6]. Available from: http://www2.inca.gov.br/wps/wcm/connect/tiposdecancer/site/home/linfoma nao hodgkin 
21. Malagutti W. Oncologia Pediátrica: uma abordagem multiprofissional. São Paulo: Martinari, 2011. 384p.

22. Macêdo TM, Campos TF, Mendes REF, França DC, Chaves GSS, Mendonça KMPP. Pulmonary function of children with acute leukemia in maintenance phase of chemotherapy. Rev Paul Pediatr [Internet]. 2014 [cited 2014 Dec 13];32(4):320-5. Available from: http://www.scielo.br/pdf/rpp/v32n4/0103-0582-rpp-32-04-00320.pdf

23. Oliveira GF, DantasFDC, Fonseca PN. O impacto da hospitalização em crianças de 1 a 5 anos de idade. Rev SBPH [Internet]. 2004 [cited 2015Jan 7];7(2):37-54.Availablefrom:http://pepsic.bvsalud.org/scielo.php?pid =S1516-08582004000200005\&script =sci_abstract

24. Marques APFS. Câncer e estresse: um estudo sobre crianças em tratamento quimioterápico. Psicol Hosp[Internet]. 2004 [cited 2015 Jan 30];2(2). Available from: http://pepsic.bvsalud.org/scielo.php?script=sci_arttext\&pid=S1677-74092004000200006

25. Martins ACF. Adaptação da escala do conforto térmico para a população portuguesa. [Dissertação]. Escola Superior de Enfermagem do Porto: Porto; 2015. $85 \mathrm{f}$

26. Fonseca AS, (Org.). Enfermagem Pediátrica. São Paulo: Martinari; 2013.

27. Coyne I. Children's experiences of hospitalization. J Child Health Care [Internet]. 2006 [cited 2017 Apr 6];104:326-36. Available from: http://journals.sagepub.com/doi/pdf/10.1177/1367493506067884 